\title{
Contribution of the Microvessel Network to the Clonal and Kinetic Profiles of Adrenal Cortical Proliferative Lesions
}

\author{
SALVADOR J. DIAZ-CANO, MD, PHD, MANUEL DE MIGUEL, PHD, \\ ALFREDO BLANES, MD, PHD, HUGO GALERA, MD, PHD, \\ AND HUBERT J. WOLFE, MD
}

\begin{abstract}
Monoclonal adrenocortical lesions have been characterized by an inverse correlation between proliferation and apoptosis, and polyclonal lesions show a direct correlation. Their relationship with the vascular pattern remains unknown in adrenocortical nodular hyperplasias (ACNHs), adenomas (ACAs), and carcinomas (ACCs). We studied 20 ACNHs, 25 ACAs, and 10 ACCs (World Health Organization classification criteria) from 55 women. The analysis included $\mathrm{X}$-chromosome inactivation assay (on microdissected samples), slide and flow cytometry, and in situ end labeling. Endothelial cells were stained with anti-CD31, and the blood vessel area and density were quantified by image analysis in the same areas. Appropriate tissue controls were run in every case. Regression analyses between kinetic and vascular features were performed in both polyclonal and monoclonal lesions. Polyclonal patterns were observed in 14 of 18 informative ACNHs and 3 of 22 informative ACAs, and monoclonal patterns were seen in 4 of 18 ACNHs, 19 of 22 ACAs, and 9 of 9 ACCs. A progressive increase in microvessel area was observed in the ACNH-ACA-ACC transition but was statistically significant between be-
\end{abstract}

Heterogeneous clonal profiles have been shown in adrenocortical proliferative lesions, ${ }^{1-3}$ with polyclonal lesions predominating in nodular hyperplasias (AC$\mathrm{NHs}$ ) and monoclonal lesions predominating in adenomas (ACAs) and carcinomas (ACCs). Similar results have also been reported in other endocrine hyperplasias ${ }^{2,4-6}$ and neoplasms, ${ }^{4-6}$ supporting the concept of multistep tumorigenesis. ${ }^{7}$ However, monoclonal hyperplasias (parathyroid, in multiple endocrine neoplasia type 1 and uremic patients, and multinodular goiters $)^{6,8}$ and polyclonal adenomas (parathyroid and thyroid) ${ }^{2}$ have also been reported. Therefore, it has been concluded that clonality assay itself is of limited utility in differentiating hyperplastic from neoplastic conditions.

From the Department of Pathology, Tufts University-New England Medical Center, Boston, MA; the Department of Pathology, Barts and The London Queen Mary's School of Medicine and Dentistry, London, England; the Department of Pathology, University Hospital of Seville, Seville, Spain; and the Department of Pathology, University Hospital of Malaga, Malaga, Spain. Accepted for publication July 10, 2001.

Presented in part at the annual meeting of the United States and Canadian Academy of Pathology, New Orleans, LA, March 25-31, 2000; and the winter meeting of the Pathological Society of Great Britain and Ireland, London, England, January 18-20, 2000.

Address correspondence and reprint requests to Salvador J. DiazCano, MD, PhD, Department of Histopathology \& Morbid Anatomy, Barts and The London, The Royal London Hospital, Whitechapel, London E1 1BB, England.

Copyright $\odot 2001$ by W.B. Saunders Company

0046-8177/01/3211-0013\$35.00/0

doi:10.1053/hupa.2001.28949 nign and malignant lesions only $(191.36 \pm 168.32 v 958.07 \pm 1279.86$ $\left.\mu^{2} ; P<.0001\right)$. In addition, case stratification by clonal pattern showed significant differences between polyclonal and monoclonal benign lesions; $6 \%$ of polyclonal and $57 \%$ of monoclonal lesions had microvessel area $>186 \boldsymbol{\mu m}^{2}(P=.0000008)$. Monoclonal lesions showed parallel trends (but with opposite signs) for microvessel area and density in comparison with proliferation and apoptosis, whereas polyclonal lesions showed inverse trends. In conclusion, the kinetic advantage of monoclonal adrenal cortical lesions (increased proliferation, decreased apoptosis) is maintained by parallel increases in microvessel area and density. Hum Pathol 32:1232-1239. Copyright $\odot 2001$ by W.B. Saunders Company

Key words: adrenal cortex, nodular hyperplasia, adenoma, carcinoma, clonality, proliferation, apoptosis, microvessel density.

Abbreviations: ACA, adrenocortical adenoma; ACC, adrenocortical carcinoma; ACNH, adrenocortical nodular hyperplasia; H\&E, hematoxylin and eosin; PCR, polymerase chain reaction; HUMARA, human androgen receptor gene; ISEL, in situ end labeling.

A distinctive correlation between proliferation and apoptosis has been demonstrated in adrenocortical proliferative lesions by clonal patterns. ${ }^{3}$ Polyclonal lesions have shown increasing apoptosis in response to increasing proliferative rates, whereas monoclonal lesions had progressively lower apoptotic rates as proliferation increased. That inverted relationship between apoptosis and proliferation in monoclonal adrenal cortical lesions also provides a functional basis for clonal selection and segregates ACNHs from neoplastic ACAs. Cell kinetics represent the basic mechanisms leading to cellular selection, which results in clonal expansion and tumor growth. ${ }^{3,9,10}$ Downregulated apoptosis has also been reported in intraepithelial neoplasms at different locations and would allow both survival and replication of genetically damaged cells, giving rise to mutation accumulation and tumor promotion. ${ }^{11-14}$ Inversely related proliferation and apoptosis in monoclonal lesions would then contribute to clonal progression in neoplasms. ${ }^{3,9,15,16}$ Tumor cell growth has been related to the capacity to induce neoangiogenesis. However, the relationship among the vascular pattern, clonality, and cell kinetics remains unknown in ACNHs, ACAs, and ACCs.

\section{MATERIALS AND METHODS \\ Case Selection and Sampling}

Consecutive adrenocortical proliferative lesions (69) were selected and histologically evaluated. ${ }^{12}$ Of these lesions, 55 were detected in female patients, including 20 ACNHs, 25 
ACAs, and 10 ACCs classified by World Health Organization criteria, ${ }^{18}$ although evidence of metastasis was the main criterion of malignancy. The mean follow-up time in this series was 159 months.

All surgical specimens were serially sectioned and embedded for routine histopathologic diagnosis (at least 1 block $/ \mathrm{cm}$ ). The most cellular areas from the biggest nodule in each case of ACNH and from every ACA and ACC were screened and selected for further analysis. The same areas were used in each analysis; hematoxylin and eosin (H\&E)stained sections taken before and after the specimen samples were used to check the cellular composition of each sample.

\section{X-Chromosome Inactivation Assay for Clonality Analysis}

Two 20- $\mu \mathrm{m}$ unstained paraffin sections were used for microdissection under microscopic control. Adrenal cortical cells and controls (histologically normal adrenal cortex, adrenal medulla, and periadrenal soft tissue from the same slide) underwent DNA extraction. At least 2 separate areas of $0.25 \mathrm{~mm}^{2}$, containing approximately 100 target cells each, were harvested from both peripheral and internal areas of the biggest nodule in ACNH, ACA, and ACC.

The samples were dewaxed with xylene, cleared with absolute ethanol, and digested with proteinase K; DNA was extracted using a modified phenol-chloroform protocol, as previously described. ${ }^{19}$ All samples were divided for restriction endonuclease digestion, using half of each sample for Hhal digestion $(0.8 \mathrm{U} / \mu \mathrm{l}$; New England Biolabs, Beverly, MA); the other half was kept as undigested control. Undigested and digested samples were processed equally, but $H$ haI was excluded in the reaction mixture in undigested samples. The samples were digested under appropriate buffer conditions $(50 \mathrm{mmol} / \mathrm{L}$ potasium acetate, $20 \mathrm{mmol} / \mathrm{L}$ Tris acetate, $10 \mathrm{mmol} / \mathrm{L}$ magnesium acetate, $1 \mathrm{mmol} / \mathrm{L}$ dithiothreitol $\mathrm{pH}$ 8.0, $100 \mu \mathrm{g} / \mathrm{mL}$ bovine serum albumin, $100 \mu \mathrm{g} / \mathrm{mL}$ mussel glycogen $)$ at $37^{\circ} \mathrm{C}$ for 4 to 16 hours. A mimicker $(0.3 \mu \mathrm{g}$ of double-stranded and XhoI-linearized $\phi X 174-R I I$ phage; Life Technologies, Inc, Gaithersburg, MD) was included in each reaction mixture. Complete digestion was checked by gel electrophoresis; incompletely digested samples were phenol chloroform-purified and redigested with higher HhaI concentration.

HhaI was then inactivated by phenol chloroform extraction as described. ${ }^{19}$ DNA was precipitated with ice-cold absolute ethanol in the presence of $0.3 \mathrm{~mol} / \mathrm{L}$ sodium acetate $(\mathrm{pH}$ 5.2) and resuspended in $10 \mu \mathrm{L}$ of polymerase chain reaction (PCR) buffer $(10 \mathrm{mmol} / \mathrm{L}$ Tris-HCl pH 8.4, $50 \mathrm{mmol} / \mathrm{L} \mathrm{KCl}$, $1.5 \mathrm{mmol} / \mathrm{L} \mathrm{MgCl}_{2}$, and $100 \mu \mathrm{g} / \mathrm{mL}$ bovine serum albumin). Both digested and undigested DNA were then used for PCR amplification of a region containing the CAG repeat in the first exon of the human androgen receptor gene (HUMARA) and a DNA sequence recognized by HhaI that is consistently methylated in the inactive HUMARA allele only. ${ }^{20-22}$ Primers and PCR cycling conditions were designed as previously described. ${ }^{21,23,24}$ The reactions were run in duplicate and optimized for a $10-\mu \mathrm{L}$ reaction in a Perkin-Elmer thermal cycler model 480 (Perkin-Elmer, Norwalk, CT).

The whole PCR volume was electrophoresed into 0.75 mm-thick $8 \%$ nondenaturing polyacrylamide gel at $5 \mathrm{~V} / \mathrm{cm}$ until a xylene cyanol band was located within the bottom inch of the gel. After fixation with $7 \%$ acetic acid ( 5 minutes), the gels were dried under vacuum $\left(80^{\circ} \mathrm{C}, 40\right.$ minutes $)$ and put inside a developing cassette containing 1 intensifying screen and preflashed films (Kodak XAR; Kodak Co, Rochester, NY) facing the intensifying screen $\left(16\right.$ to 48 hours, $\left.-70^{\circ} \mathrm{C}\right)$. The autoradiograms were developed using an automated processor Kodak-Omat 100.

Allelic imbalance was densitometrically evaluated (EC model 910 optical densitometer; EC Apparatus Corp, St Petersburg, FL), and evidence of monoclonal proliferation was considered to be allele ratios $\geq 4: 1$ with the normalized HhaIdigested samples. Sample normalization was done in relation to the corresponding undigested sample and tissue controls. Only informative cases (2 different alleles in $\mathrm{HhaI}$-undigested and HhaI-digested samples) were included in the final analysis. ${ }^{21,23-26}$

\section{Slide Cytometric Analysis of DNA Content}

Several Feulgen-stained $5-\mu \mathrm{m}$ sections were used for DNA quantification according to previously published protocols that have proven valid in such material. ${ }^{14,27,28}$ Densitometric evaluation was performed using the cell analysis system model 200 and the quantitative DNA analysis package as software (Becton Dickinson, Franklin Lakes, NJ). At least 200 nuclei were measured in every case, beginning in the most cellular area through completion in consecutive microscopic high-power fields. Only complete, nonoverlapping, and focused nuclei were quantified in each field. ${ }^{27}$

External staining calibration was carried out with complete rat hepatocytes (Becton Dickinson; 1 slide per staining holder) to normalize the internal controls; the latter included both lymphocytes and adrenocortical cells from histologically normal areas present in the same tissue section. The internal controls were used to set the $G_{0} / G_{1}$ cell limits and calculate the DNA index of each $G_{0} / G_{1}$ peak ( $>10 \%$ of measured cells with evidence of $\mathrm{G}_{2}+\mathrm{M}$ cells).27,29 The proliferation rate $\left(\mathrm{PR}=\mathrm{S}-+\mathrm{G}_{2^{-}}+\right.$M-phase fraction $)$was calculated from the DNA histogram by subtracting the number of cells within $\mathrm{G}_{0} / \mathrm{G}_{1}$ limits from the total number of cells measured. The values were compared with total cell number and expressed as percentages. ${ }^{14,29}$

\section{Nuclear DNA Quantification by Flow Cytometry}

Serial $50-\mu \mathrm{m}$-thick sections were microdissected, and nuclear preparations were stained with propidium iodine after RNase A digestion to study DNA ploidy (by the technique of Hedley et $\left.\mathrm{al}^{30}\right)$. DNA quantification parameters included DNA indices and PRs as described, ${ }^{3,29}$ and the scatter analysis of nuclear area and DNA content allowed identification of apoptotic cells in each cell cycle phase (low nuclear area for a given DNA content in each cell cycle phase). ${ }^{31}$ Those results were additionally coupled with in situ end labeling (ISEL) to identify apoptotic cells in terms of DNA fragmentation (see below). External diploid controls from paraffin-embedded tissues (lymphocyte from reactive lymph nodes and adrenal cortical cells from histologically normal adrenal glands) were used to determine DNA indices and to standardize the nuclear area/DNA content analysis (considering only adrenal cortical cells for the last purpose) ${ }^{3}$ Proliferation rate (PR) was calculated as described for slide cytometry, using the rectangular model for evaluation of the cell cycle histogram. ${ }^{29}$

\section{ISEL of Fragmented DNA}

Extensive DNA fragmentation associated with apoptosis was detected by ISEL as previously reported. ${ }^{13,14,32}$ After routine dewaxing and hydration, the sections were incubated in $2 \mathrm{x}$ standard saline citrate $\left(20\right.$ minutes at $\left.80^{\circ} \mathrm{C}\right)$ and digested 
with proteinase $\mathrm{K}(100 \mu \mathrm{g} / \mathrm{mL}$ in Tris-HCl, $\mathrm{pH} 7.6$, for 30 minutes at room temperature) in a moist chamber.

DNA fragments were labeled on $5^{\prime}$-protuding termini by incubating the sections with the Klenow fragment of Escherichia coli DNA polymerase I $(20 \mathrm{U} / \mathrm{mL}$ in $50 \mathrm{mmol} / \mathrm{L}$ Tris$\mathrm{HCl}, \mathrm{pH} 7.5 ; 10 \mathrm{mmol} / \mathrm{L} \mathrm{MgCl}_{2} ; 1 \mathrm{mmol} / \mathrm{L}$ dithiothreitol; $250 \mu \mathrm{g} / \mathrm{mL}$ bovine serum albimin; $5 \mu \mathrm{m}$ of each deoxyadenosine triphosphate, deoxycytidine triphosphate, and deoxyguanosine triphosphate; $3.25 \mu \mathrm{mol} / \mathrm{L}$ deoxythymidine triphosphate; and $1.75 \mu \mathrm{mol} / \mathrm{L}$ 11-digoxigenin-deoxyuridine triphosphate) at $37^{\circ} \mathrm{C}$ in a moist chamber. The incorporated digoxigenin-deoxyuridine monophosphates were immunoenzymatically detected by using antidigoxigenin Fab fragments labeled with alkaline phosphatase $(7.5 \mathrm{U} / \mathrm{mL}$, in $100 \mathrm{mmol} / \mathrm{L}$ Tris-HCl pH 7.6, $150 \mathrm{mmol} / \mathrm{L} \mathrm{NaCl}, 1 \%$ bovine serum albumin) for 4 hours at room temperature. The reactions were developed with the mixture nitroblue tetrazolium-X phosphate in $100 \mathrm{mmol} / \mathrm{L}$ Tris-HCl pH 9.5, 100 $\mathrm{mmol} / \mathrm{L} \mathrm{NaCl}, 50 \mathrm{mmol} / \mathrm{L} \mathrm{MgCl}_{2}$ under microscopic control. Appropriate controls were simultaneously run, including positive (reactive lymph node), negative (same conditions omitting DNA polymerase I), and enzymatic (DNase I digestion before the end labeling). The enzymatic controls were used to reliably establish the positivity threshold in each sample.

The ISEL index was expressed as percentages of positive nuclei referred to the total number of adrenal cortical cells present in the same high-power field. ${ }^{14,33,34}$ At least 50 consecutive high-power fields were screened, beginning in the most cellular area (from the biggest nodule for ACNH).

\section{Evaluation of Microvessel Pattern}

The sections were mounted on positively charged microscope slides (Superfrost Plus; Fisher Scientific, Fair Lawn, NJ) and baked at $60^{\circ} \mathrm{C}$ for 2 hours. The slides were routinely dewaxed and rehydrated. The endogenous peroxidase activity was then quenched with $0.5 \% \quad \mathrm{H}_{2} \mathrm{O}_{2}$ in methanol, 10 minutes). A microwave antigen-retrieval method (20 minutes in $10 \mathrm{mmol} / \mathrm{L}$ citrate buffer, $\mathrm{pH} 6.0$, at $600 \mathrm{~W}$ ) was used, followed by incubation with polyclonal horse serum (20 minutes, 1:100 dilution; Dako, Glostrup, Denmark) and with monoclonal anti-CD31 antibody (overnight at $4^{\circ} \mathrm{C}$ ) at 2 $\mu \mathrm{g} / \mathrm{mL}$ (Dako). Sections were then serially incubated with biotinylated antimouse antibody (30 minutes, 1:200 dilution; Dako) and peroxidase-labeled avidin-biotin complex (60 minutes, 1:100 dilution; Dako). All incubations were performed in a moist chamber at room temperature unless otherwise specified. The reaction was developed under microscopic control, using 3,3'-diaminobenzidine tetrahydrochloride with $0.3 \% \mathrm{H}_{2} \mathrm{O}_{2}$ as chromogen (Sigma Chemical, St Louis, MO), and the sections were counterstained with hematoxylin. Both positive (reactive lymph node) and negative (omitting the primary antibody) controls were simultaneously run.

Blood vessel morphometry was evaluated in at least 20 medium-power fields (100x), using a computer-aided image analysis system (Kontron MOP Videoplan). The area and perimeter of each blood vessel and the number of blood vessels were measured per square millimeter, mean and SD were determined. The total vascular area results from the product of the number of microvessels times the microvessel average area. Therefore, an inverse correlation between microvessel number and area per square millimeter should be expected for a given total vascular area. Imbalances of that correlation result in decreased or increased vascularization compared with the standard. Area/perimeter correlation per microvessel informs on the blood vessel shape.

Standard values for these microvessel variables were obtained from 10 histologically normal adrenal glands excised for extraadrenal pathology (ie, renal cell carcinoma). The upper limits of the $95 \%$ confidence intervals were area, 186 $\mu \mathrm{m}^{2} / \mathrm{mm}^{2}$; perimeter, $56 \mu \mathrm{m}$; and density, 50 microvessels/ $\mathrm{mm}^{2}$.

\section{Statistical Analysis of Quantitative Variables}

The results of microvessel variables were compared by diagnostic group (ACNH/ACA/ACC) and by clonality pattern in benign lesions (polyclonal $v$ monoclonal). Variables showing normal distribution were analyzed using the Student $t$ test, whereas analyses of variance were used for variables with nonparametric distribution. Normal distribution was previously tested by the Kolmogorov-Smirnoff test. Microvessel variables were also categorized and analyzed by the Fisher exact test using the following thresholds: microvessel area, $186 \mu \mathrm{m}^{2}$; microvessel perimeter, $56 \mu \mathrm{m}$; microvessel density, $50 / \mathrm{mm}^{2}$. The results were considered statistically significant at $P<.05$ in 2-tailed distributions. Regression analyses were also performed to test the correlation between microvessel variables, proliferation, and apoptosis in both polyclonal and monoclonal lesions.

\section{RESULTS}

Polyclonal patterns were observed in $14(78 \%)$ of 18 informative ACNHs and $3(14 \%)$ of 22 informative ACAs, and monoclonal patterns were seen in $4(22 \%)$ of 18 ACNHs, $19(86 \%)$ of 22 ACAs, and $9(100 \%)$ of 9 ACCs. The sequence ACNH-ACA-ACC was characterized by a progressive increased in proliferation and apoptosis markers as well as in microvessel area and perimeter (Table 1, Fig 1), but differences were statistically significant only in comparisons between benign

TABLE 1. Microvessel Morphometry and Kinetic Features in Adrenocortical Proliferative Lesions

\begin{tabular}{|c|c|c|c|c|}
\hline & $\begin{array}{c}\text { ACNH } \\
(\text { Mean } \pm \text { SD })\end{array}$ & $\begin{array}{c}\text { ACA } \\
(\text { Mean } \pm \text { SD })\end{array}$ & $\begin{array}{c}\text { ACC } \\
(\text { Mean } \pm \text { SD })\end{array}$ & $\begin{array}{c}\text { Statistical } \\
\text { Significance }\end{array}$ \\
\hline Vessel area $\left(\mu \mathrm{m}^{2} / \mathrm{mm}^{2}\right)$ & $157.23 \pm 123.61$ & $216.32 \pm 200.34$ & $958.07 \pm 1279.86$ & $P=.0001$ \\
\hline Vessel perimeter $\left(\mu \mathrm{m} / \mathrm{mm}^{2}\right)$ & $48.81 \pm 10.15$ & $55.04 \pm 14.05$ & $135.36 \pm 108.58$ & $P<.0001$ \\
\hline Vessel density $\left(\right.$ no. $\left./ \mathrm{mm}^{2}\right)$ & $67.28 \pm 45.90$ & $59.50 \pm 37.05$ & $34.40 \pm 19.61$ & NS \\
\hline \multicolumn{5}{|l|}{ Proliferation rate } \\
\hline Slide Cytometry (\%) & $16.67 \pm 9.42$ & $22.59 \pm 11.03$ & $34.17 \pm 8.84$ & $P=.0002$ \\
\hline Flow Cytometry (\%) & $13.64 \pm 5.73$ & $13.69 \pm 6.29$ & $23.49 \pm 5.60$ & $P=.0002$ \\
\hline ISEL & $0.58 \pm 0.19$ & $1.03 \pm 0.52$ & $4.55 \pm 1.52$ & $P<.0001$ \\
\hline
\end{tabular}


Units $/ \mathrm{mm}^{2}$

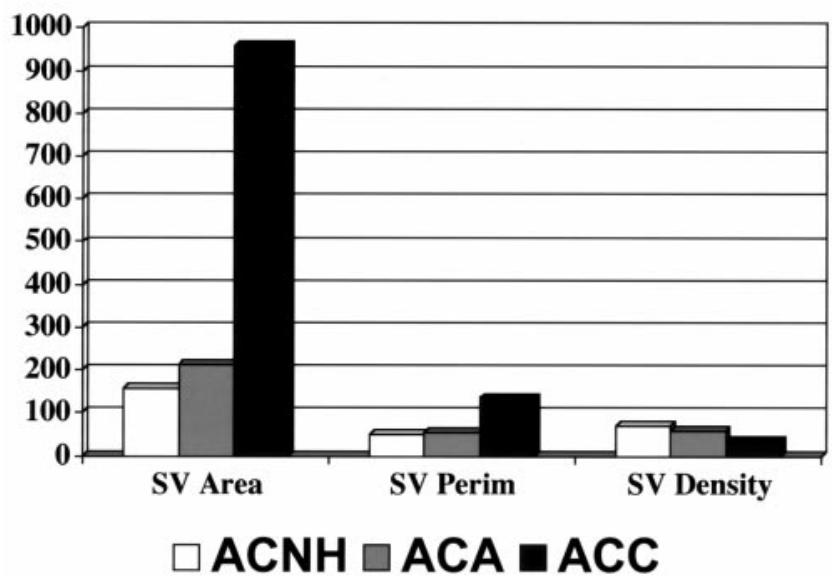

FIGURE 1. Morphometric features of small vessels (SV) in AC$\mathrm{NHs}$, ACAs, and ACCs. All morphometric variables showed significant differences for the distinction between ACNH-ACA and ACC. Units $/ \mathrm{mm}^{2}$ : area $=\mu \mathrm{m}^{2}$; density = number; perimeter $=\mu \mathrm{m}$.

(ACNH and ACA) and malignant (ACC) conditions (Fig 2). In contrast, microvessel density decreased progressively in the same transition (Table 1). Case classification of benign lesions by clonal pattern only revealed significant differences for the proliferation rate estimated by slide cytometry (Table 2, Fig 3). After case categorization, statistically significant differences were also revealed for microvessel area $(6 \%$ of polyclonal and $57 \%$ of monoclonal lesions had microvessel area
TABLE 2. Microvessel Morphometry and Kinetic Features by Clonal Patterns in Benign Adrenocortical Proliferative Lesions

\begin{tabular}{lccc}
\hline & $\begin{array}{c}\text { Polyclonal } \\
\text { Lesions } \\
(\text { Mean } \pm \mathrm{SD})\end{array}$ & $\begin{array}{c}\text { Monoclonal } \\
\text { Lesions } \\
(\text { Mean } \pm \mathrm{SD})\end{array}$ & $\begin{array}{c}\text { Statistical } \\
\text { Significance }\end{array}$ \\
\hline $\begin{array}{c}\text { Vessel area } \\
\left(\mu \mathrm{m}^{2} / \mathrm{mm}^{2}\right)\end{array}$ & $157.53 \pm 128.42$ & $233.90 \pm 204.43$ & $\mathrm{NS}$ \\
$\begin{array}{c}\text { Vessel perimeter } \\
\left(\mu \mathrm{m} / \mathrm{mm}^{2}\right)\end{array}$ & $49.98 \pm 10.55$ & $55.79 \pm 14.32$ & $\mathrm{NS}$ \\
$\begin{array}{c}\text { Vessel density } \\
\left(\text { no. } / \mathrm{mm}^{2}\right)\end{array}$ & $65.74 \pm 40.18$ & $54.18 \pm 37.92$ & $\mathrm{NS}$ \\
$\begin{array}{c}\text { Proliferation rate } \\
\text { Slide cytometry } \\
(\%)\end{array}$ & $15.53 \pm 7.85$ & $22.73 \pm 10.71$ & $P=.0187$ \\
$\begin{array}{c}\text { Flow cytometry } \\
(\%)\end{array}$ & $13.54 \pm 6.36$ & $13.02 \pm 5.36$ & $\mathrm{NS}$ \\
ISEL & $0.68 \pm 0.41$ & $0.90 \pm 0.31$ & $\mathrm{NS}$ \\
\hline & & &
\end{tabular}

$>186 \mu \mathrm{m}^{2} ; P=.0000008$ ), whereas the distribution of microvessel perimeter and density was not significantly different. Using cytometric criteria, apoptotic cells were detected in 10 benign cases, 8 with microvessel area $<186 \mu \mathrm{m}^{2}$ (4 polyclonal and 4 monoclonal; $P=.0088$ ) and 2 with microvessel density $<50 / \mathrm{mm}^{2}$ (both cases monoclonal; $P=.0002$; Fig 2 ). All malignant tumors also showed apoptotic cells in flow cytometry, but with no correlation with the microvessel pattern.

Figures 4 and 5 show the relationship between microvessel and kinetic features. Polyclonal lesions had an inverse correlation between microvessel area and both proliferation and apoptosis (Fig 4A, B), whereas
FIGURE 2. Microvessel network in adrenal cortical lesions shown by CD31 immunostaining. Polyclonal lesions showed delicate microvessels with small total vascular area (A, nodular hyperplasia, original magnification $\times 100$; $\mathrm{B}$, adenoma, original magnification $\times 100$ ) whereas monoclonal lesions showed dilated microvessels and increased total vascular area (C, adenoma, original magnification $\times 200$; $D$, carcinoma, original magnification $\times 200$ ).

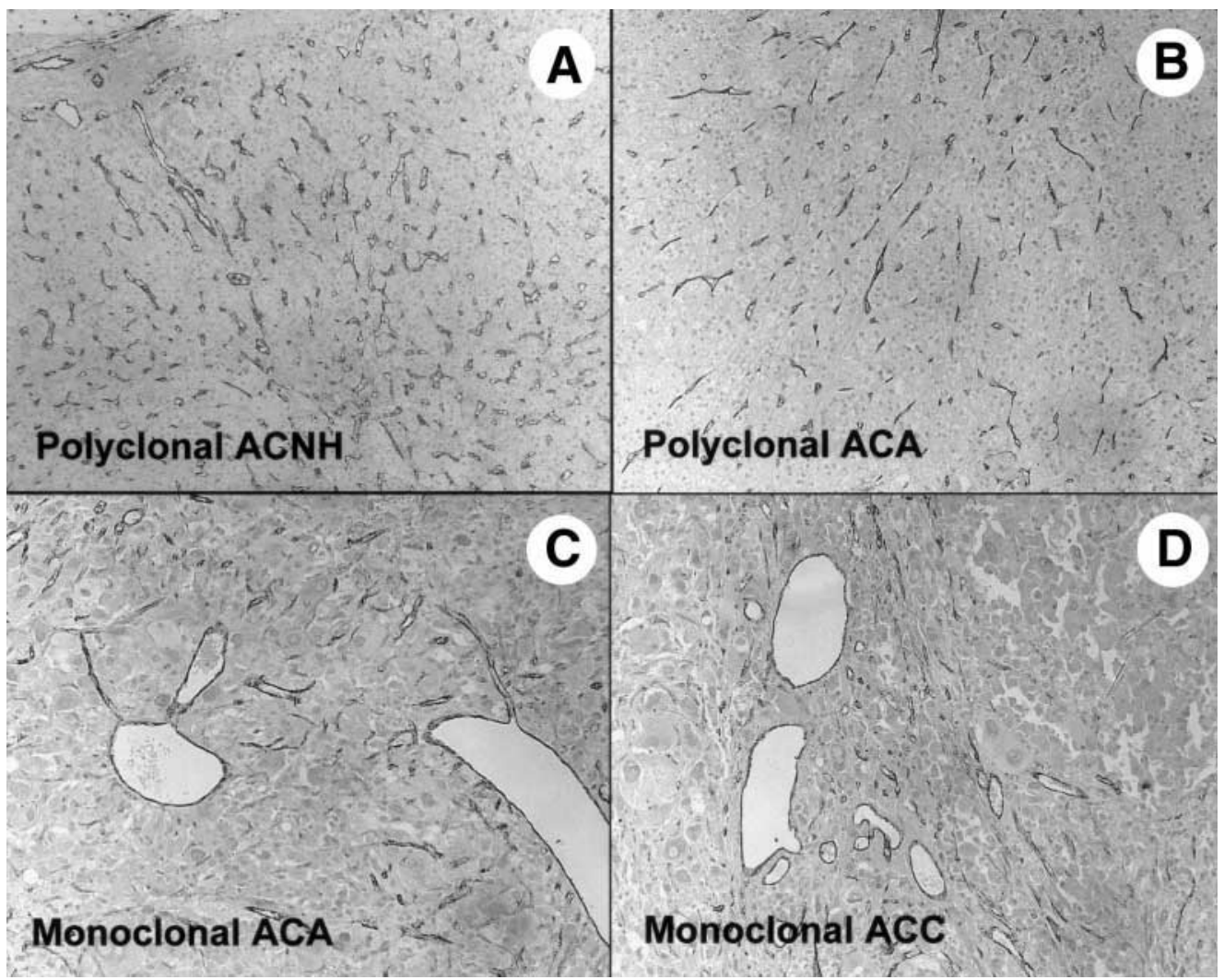



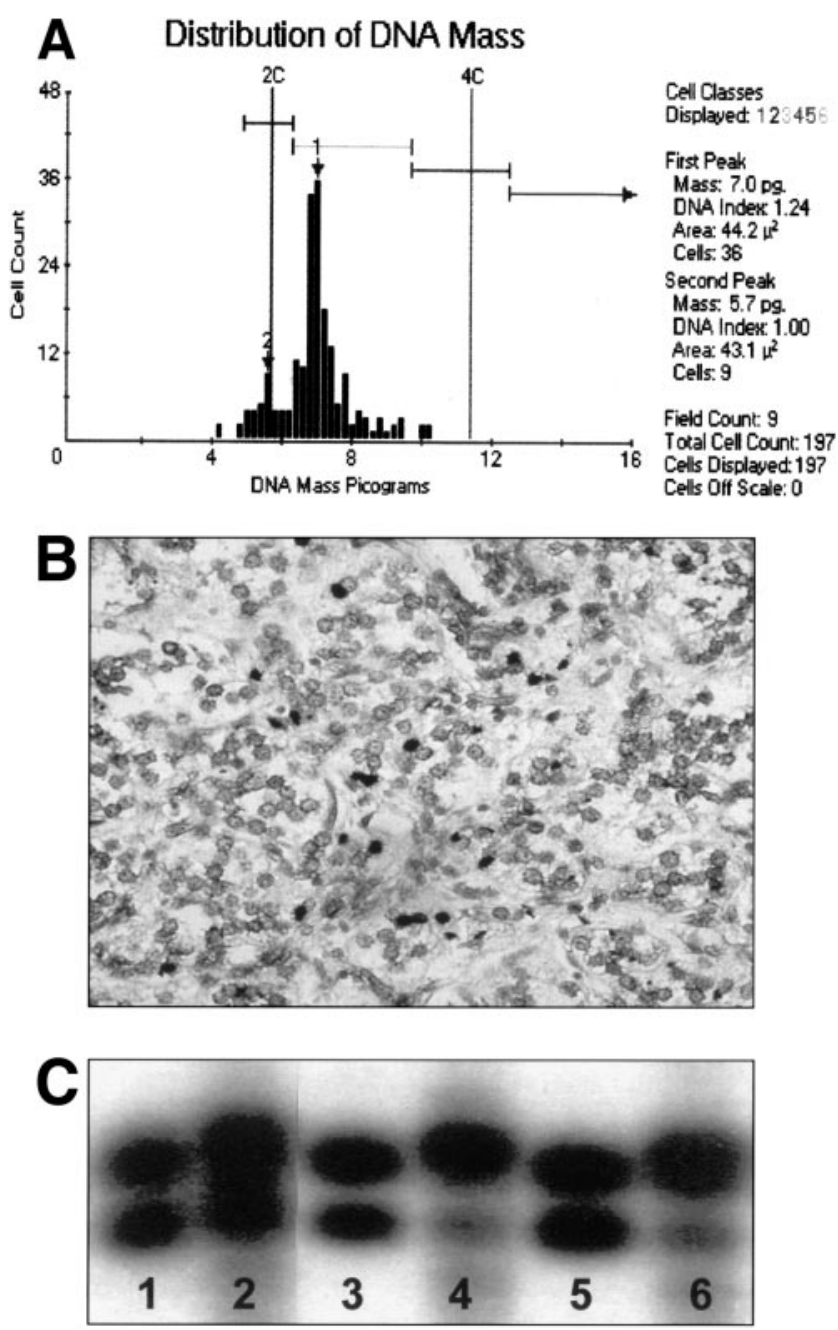

FIGURE 3. (A) DNA ploidy and (B) ISEL in a monoclonal ACA. The larger allele was preferentially methylated in both peripheral (lanes 3, undigested DNA, and 4, digested DNA) and internal (lanes 5, undigested DNA, and 6, digested DNA) samples, and the control sample was polyclonal (C, lanes 1, undigested DNA, and 2, digested DNA). Apoptosis was shown by cells with low nuclear area/DNA content (preceding peak 2 in A) and by nuclear staining using ISEL (B).

the correlation was direct between microvessel density and both proliferation and apoptosis (Fig 4C, D). In contrast, monoclonal lesions had direct correlation between proliferation and both area and density of microvessels (Fig 5A, C) but an inverse correlation between apoptosis and microvessel area and density (Fig $5 \mathrm{~B}, \mathrm{D})$. A linear correlation was demonstrated in all these analyses.

\section{DISCUSSION}

The microvascular pattern of adrenocortical lesions showed a significant increase in the vascular area in ACCs compared with benign adrenocortical lesions (ACNHs and ACAs) and a distinctive relationship between proliferation and apoptosis in monoclonal benign proliferative lesions. The increase in both mi- crovessel area and microvessel density helps maintain the inverted relationship between apoptosis and proliferation in monoclonal adrenocortical lesions, providing a functional basis for clonal selection in ACNHs and ACAs.

Monoclonal lesions showed a distinctive correlation of microvessel area and density with proliferation (direct) and apoptosis (inverse), which would facilitate self-maintained growth. The microvessel pattern was shown to be significantly different for ACCs and for monoclonal benign adrenocortical lesions. These findings support the important role postulated for angiogenesis in tumor cell kinetic and progression of endocrine tumors, including adrenocortical neoplasms. The mean microvessel area and the total vascular area was significantly higher in ACCs than in ACNHs and ACAs, similar to results previously reported, ${ }^{35}$ but no significant differences between benign adrenocortical lesions were seen. An inverse relationship between microvessel area and density must be expected under physiologic conditions. This scenario was proved in polyclonal lesions: proliferation and apoptosis showed a direct correlation with each other and with microvessel density but an inverse correlation with microvessel area. The opposite situation (direct relationship between microvessel area and density) was observed for monoclonal lesions: inverse correlation between proliferation and apoptosis, with greater microvessel area and density in lesions with high proliferation rate and low apoptosis index. These 2 microvessel factors (high area and density) help maintain the kinetic advantage related to high proliferation and low apoptosis. The increased blood supply contributes to cell proliferation, providing oxygen and nutrients for cycling cells on 1 hand and, on the other hand, trophic/growth factors essential in most endocrine organs. The absence of these factors results in endocrine gland atrophy by apoptosis.9,36 A less efficient blood supply of growing glands helps increase their apoptotic rate, thus resulting in parallel trends of proliferation and apoptosis. A better supply overrides apoptosis, explaining the inverse proliferation/apoptosis correlation because of apoptosis downregulation in monoclonal lesions. Eventually, these 2 kinetic parameters will segregate monoclonal proliferation with ACAs rather than with ACNHs $^{3}$

The distinctive microvessel pattern represents a key element to explain the kinetic abnormalities leading to tumor promotion. Cell kinetics represent the basic mechanisms leading to clonal expansions and tumor growths. ${ }^{3,9,10}$ In terms of the correlation between apoptosis and proliferation, polyclonal lesions showed increasing apoptosis in response to increasing proliferative rates. However, monoclonal lesions had progressively lower apoptotic rates as proliferation increased. That inverted relationship between apoptosis and proliferation in monoclonal adrenocortical lesions also provides a functional basis for clonal selection and segregates ACNHs from neoplastic ACAs. The correlation between proliferation and apoptosis provides rules for cellular selection, ie, clonal expansion or regres- 

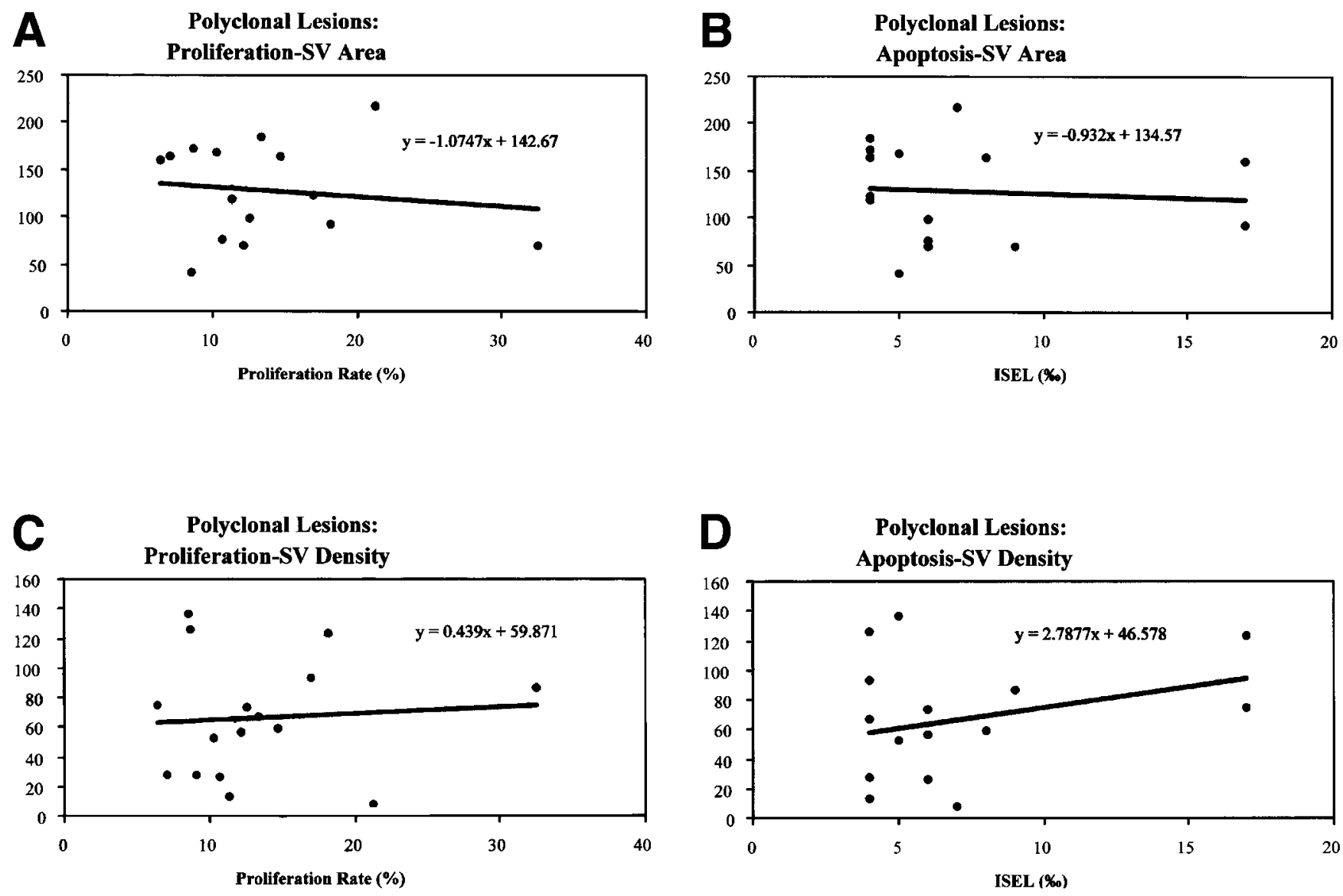

FIGURE 4. Parallel correlations were seen in polyclonal lesions for (A, C) proliferation and (B, D) apoptosis in their comparison with (A, B) small vessel (SV) area (negative correlation) and (C, D) SV density (positive correlation).

sion. Downregulated apoptosis (as revealed by ISEL) has been reported in intraepithelial neoplasms of different locations and would allow both survival and replication of genetically damaged cells, giving rise to mutation accumulation in those cells.11,13,14 A maintained cell proliferation would transmit those genetic changes into descendant cells, and a relatively blocked apoptotic process would allow genetically damaged cells to complete the replication cycle, ending in mutation accumulation and tumor promotion. ${ }^{12}$ This inverted correlation with maintained proliferation and downregulated apoptosis is substantiated by increasing the effective vascular area and by decreasing the distance between proliferating cells and microvessels (higher density). This pattern also contribute to clonal progression, whereas the opposite scenario would lead to clone regression. ${ }^{3,9,14,15}$

The microvessel pattern can also help explain histologic findings in adrenocortical proliferative lesions. Interstitial fibrin deposition from leaky tumor vessels provides a provisional stroma that serves to regulate the influx of inflammatory cells and facilitates the inward migration of new blood vessels and fibroblasts, the mature tumor stroma. ${ }^{37}$ That process has shown a pivotal role in promoting tumor growth. ${ }^{38}$ Stromal and vascular proliferations in tumors have been described in both adrenocortical and medullary neoplasms, 3,39 either as reactions to invasion or as expressions of regression. This vascular supply helps increase the proliferation rate and the proportion of tetraploid cells (because of nondisjunctional mitoses). ${ }^{27,39,40}$ The apoptotic rate increased significantly only for ACCs, for which the accumulation of genetic alterations would lead to lethal effects.

ACNHs and ACAs showed a heterogeneous clonal profile, as previously reported, ${ }^{1,2}$ with polyclonal lesions predominating in ACNHs and monoclonal lesions predominating in ACAs and ACCs. ${ }^{3}$ Endocrine hyperplasias have shown polyclonal patterns, ,2,-6 whereas most endocrine adenomas have been reported monoclonal. ${ }^{4-6}$ Those findings support the concept of multistep tumorigenesis. ${ }^{41}$ Monoclonal lesions showed significantly higher proliferation and microvessel area (Table 2), although heterogeneity was the most remarkable finding for all features. Proliferation of unselected cells would explain that heterogeneity and correlates with the cell-selection process activated during neoplastic transformation, which is essentially maintained by the microvessel network. Any kinetic advantage in small cell groups sharing a given genetic background would result in their preferential growth, thus yielding an overall monoclonal pattern, ${ }^{42}$ even in early stages. ${ }^{43,44}$

In conclusion, the microvessel profile of monoclo- 

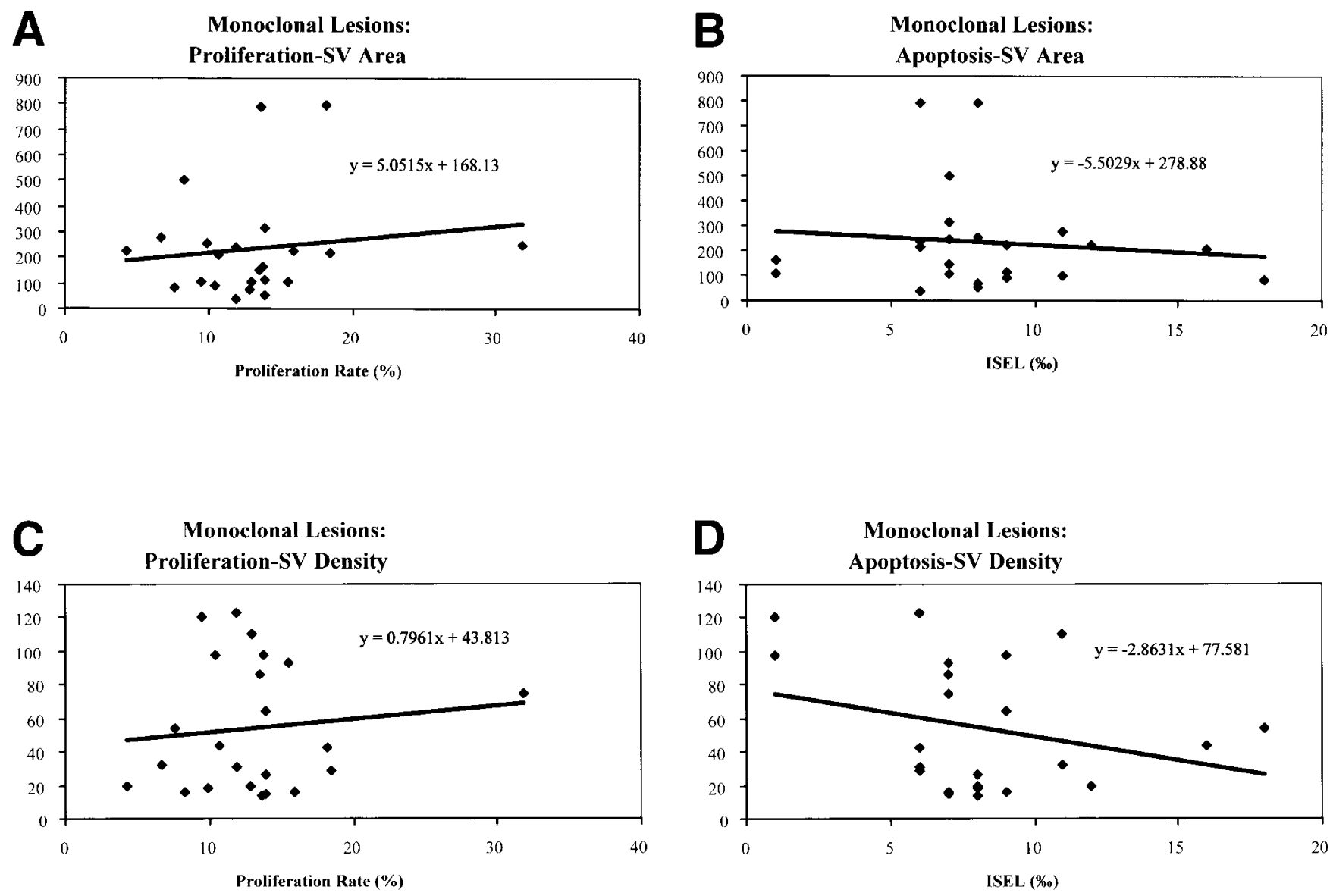

FIGURE 5. Parallel and direct correlation between proliferation and both (A) small vessel (SV) area and (B) density was observed in monoclonal adrenal cortical lesions. (B, D) In contrast, the correlation was parallel and inverse for apoptosis. Lesions showing high proliferation and low apoptosis displayed high vascular area and density simultaneously.

nal adrenocortical lesions is characterized by parallel increases in microvessel area and density that correlate directly with proliferation and inversely with apoptosis. This distinctive microvessel pattern certainly helps maintain the kinetic advantage (high proliferation and low apoptosis), clonal cell selection, and eventually cellular progression in those lesions.

\section{REFERENCES}

1. Beuschlein F, Reincke M, Karl M, et al: Clonal composition of human adrenocortical neoplasms. Cancer Res 54:4927-4932, 1994

2. Jackson CE, Cerny JC, Block MA, et al: Probable clonal origin of aldosteronomas versus multicellular origin of parathyroid "adenomas." Surgery 92:875-879, 1982

3. Diaz-Cano SJ, de Miguel M, Blanes A, et al: Clonality as expression of distinctive cell kinetics patterns in nodular hyperplasias and adenomas of the adrenal cortex. Am J Pathol 156:311-319, 2000

4. Noguchi S, Motomura K, Inaji $\mathrm{H}$, et al: Clonal analysis of parathyroid adenomas by means of the polymerase chain reaction. Cancer Lett 78:93-97, 1994

5. Aeschimann S, Kopp PA, Kimura ET, et al: Morphological and functional polymorphism within clonal thyroid nodules. J Clin Endocrinol Metab 77:846-851, 1993

6. Apel RL, Ezzat S, Bapat BV, et al: Clonality of thyroid nodules in sporadic goiter. Diagn Mol Pathol 4:113-121, 1995

7. Knudson AG Jr: Mutation and cancer: a personal odyssey. Adv Cancer Res 67:1-23, 1995
8. Friedman E, Sakaguchi K, Bale AE, et al: Clonality of parathyroid tumors in familial multiple endocrine neoplasia type 1. N Engl J Med 321:213-218, 1989

9. Salomon RN, Diaz-Cano S: Introduction to apoptosis. Diagn Mol Pathol 4:235-238, 1995

10. Diaz-Cano SJ: Clonality studies in the analysis of adrenal medullary proliferations: Application principles and limitations. Endocr Pathol 9:301-316, 1998

11. Kerr JF, Wyllie AH, Currie AR: Apoptosis: A basic biological phenomenon with wide-ranging implications in tissue kinetics. Br J Cancer 26:239-257, 1972

12. Isaacs JT: Role of programmed cell death in carcinogenesis. Environm Health Persp 101:27-34, 1993 (suppl 5)

13. Diaz-Cano SJ, Garcia-Moliner M, Carney W, et al: Bcl-2 expression and DNA fragmentation in breast carcinoma, pathologic and steroid hormone receptors correlates. Diagn Mol Pathol 6:199208, 1997

14. Koch M, de Miguel M, Höfler H, et al: Kinetic profiles of intraepithelial and invasive prostatic neoplasias: the key role of downregulated apoptosis in tumor progression. Virchows Arch 436:413420,2000

15. Sasano H, Imatani A, Shizawa S, et al: Cell proliferation and apoptosis in normal and pathologic human adrenal. Mod Pathol 8:11-17, 1995

16. Cordon-Cardo C: Mutations of cell cycle regulators. Biological and clinical implications for human neoplasia. Am J Pathol 147:545-560, 1995

17. Diaz-Cano SJ, Leon MM, de Miguel M, et al: Diagnostic and prognostic parameters in adrenal cortical proliferative lesions: A critical review. Lab Invest 74:47A, 1996

18. Williams ED, Siebenmann RE, Sobin LH: Histological typing 
of endocrine tumours. Geneva, Switzerland, World Health Organization, 1980

19. Diaz-Cano SJ, Brady SP: DNA extraction from formalinfixed, paraffin-embedded tissues: Protein digestion as a limiting step for retrieval of high-quality DNA. Diagn Mol Pathol 6:342-346, 1997

20. Allen RC, Zoghbi HY, Moseley AB, et al: Methylation of $H p a I I$ and $H h a I$ sites near the polymorphic CAG repeat in the human androgen-receptor gene correlates with $\mathrm{X}$ chromosome inactivation. Am J Hum Genet 51:1229-1239, 1992

21. Mutter GL, Boynton KA: PCR bias in amplification of androgen receptor alleles, a trinucleotide repeat marker used in clonality studies. Nucleic Acids Res 23:1411-1418, 1995

22. Sleddens HF, Oostra BA, Brinkmann AO, et al: Trinucleotide repeat polymorphism in the androgen receptor gene (AR). Nucleic Acids Res 20:1427, 1992

23. Mutter GL, Chaponot ML, Fletcher JA: A polymerase chain reaction assay for non-random $\mathrm{X}$ chromosome inactivation identifies monoclonal endometrial cancers and precancers. Am J Pathol 146: 501-508, 1995

24. Diaz-Cano SJ, Blanes A, Wolfe HJ: PCR techniques for clonality assays. Diagn Mol Pathol 10:24-33, 2001

25. Diaz-Cano SJ, Blanes A, Rubio J, et al: Molecular evolution and intratumor heterogeneity by topographic compartments in muscle-invasive transitional cell carcinoma of the urinary bladder. Lab Invest 80:279-289, 2000

26. Diaz-Cano SJ: Designing a molecular analysis of clonality in tumours. J Pathol 191:343-344, 2000

27. Diaz-Cano S, Gonzalez-Campora R, Rios-Martin JJ, et al: Nuclear DNA patterns in adrenal cortex proliferative lesions. Virchows Arch A Pathol Anat Histopathol 423:323-328, 1993

28. Bibbo M, Bartels PH, Dytch HE, et al: Cell image analysis, in Bibbo M (ed): Comprehensive Cytopathology. Philadelphia, PA, Saunders, 1991, pp 965-983

29. Dressler LG: Controls, standards, and histogram interpretation in DNA flow cytometry. Methods Cell Biol 33:157-171, 1990

30. Hedley DW, Friedlander ML, Taylor IW, et al: Method for analysis of cellular DNA content of paraffin-embedded pathological material using flow cytometry. J Histochem Cytochem 31:1333-1335, 1983
31. Sherwood SW, Schimke RT: Cell cycle analysis of apoptosis using flow cytometry. Methods Cell Biol 46:77-97, 1995

32. Wijsman JH, Jonker RR, Keijzer R, et al: A new method to detect apoptosis in paraffin sections: In situ end-labeling of fragmented DNA. J Histochem Cytochem 41:7-12, 1993

33. Diaz-Cano SJ, Leon MM, de Miguel M, et al: Mitotic index quantification: Different approaches and their value in adrenocortical proliferative lesions. Lab Invest 74:170A, 1996

34. Harjacek M, Diaz-Cano S, Alman BA, et al: Prominent Expression of mRNA for proinflammatory cytokines in synovium in patients with juvenile rheumatoid arthritis or chronic lyme arthritis. J Rheumatol 27:497-503, 2000

35. Sasano H, Ohashi Y, Suzuki T, et al: Vascularity in human adrenal cortex. Mod Pathol 11:329-333, 1998

36. Vaux DL: Toward an understanding of the molecular mechanisms of physiological cell death. Proc Natl Acad Sci USA 90:786789., 1993

37. Nagy JA, Brown LF, Senger DR, et al: Pathogenesis of tumor stroma generation: A critical role for leaky blood vessels and fibrin deposition. Biochim Biophys Acta 948:305-326, 1989

38. Dvorak HF, Sioussat TM, Brown LF, et al: Distribution of vascular permeability factor (vascular endothelial growth factor) in tumors: concentration in tumor blood vessels. J Exp Med 174:12751278,1991

39. Diaz-Cano SJ, de Miguel M, Blanes A, et al: Clonal patterns in phaechromocytomas and MEN-2A adrenal medullary hyperplasias: Histologic and kinetic correlates. J Pathol 192:221-228, 2000

40. Gonzalez-Campora R, Diaz Cano S, Lerma-Puertas E, et al: Paragangliomas. Static cytometric studies of nuclear DNA patterns. Cancer 71:820-824, 1993

41. Knudson AG Jr, Hethcote HW, Brown BW: Mutation and childhood cancer: A probabilistic model for the incidence of retinoblastoma. Proc Natl Acad Sci USA 72:5116-5120, 1975

42. Jacoby LB, Hedley-Whyte ET, Pulaski K, et al: Clonal origin of pituitary adenomas. J Neurosurg 73:731-735, 1990

43. Nowell PC: The clonal evolution of tumor cell populations. Science 194:23-28, 1976

44. Hicks DG, LiVolsi VA, Neidich JA, et al: Clonal analysis of solitary follicular nodules in the thyroid. Am J Pathol 137:553-562, 1990 